A few experiments were made with zinc sulphate and the above observations extended, but not completed.

UNIVERSITY OF NORTH CAROLINA, April 23, Igur.

\title{
THE ACTION OF ZINC ETHYL UPON NITRO AND NITROSO COMPOUNDS.
}

\author{
(A REPLY TO I. BEWAD.) \\ By Arthle lachman. \\ Received September a8, 1gor.
}

I $\mathrm{N}$ a recent paper containing a wealth of experimental material,

I. Bewad undertakes to prove the complete analogy of the action of zinc ethyl on carbonyl compounds on the one hand, and upon nitrogen-oxygen compounds on the other. This work was begun about fourteen years ago, ${ }^{1}$ but its most important results were not manifest, or at any rate were not published in accessible journals, until last year. ${ }^{2}$ In his last paper Bewad is anxious to claim priority for these results, evidently with reference to my own publications, ${ }^{3}$ since the general subject has not been investigated by any third party.

Bewad's priority in this work is unquestioned. In fact, it was through a study of Bewad's own publications that I was led to attempt the main problem I have undertaken; viz., the intimate structure of the nitro group. Priority, however, is no guarantee of accuracy ; and since Beward has been, and is still, in error as to some matters of fact, and is entirely at sea with his explanations of other facts, I have thought it desirable to clear up several points that would seem reasonably certain, before proceeding with new experimental work.

In order to indicate that Bewad's results in the past have needed revision, let me briefly append a history of events. In his first papers ( $c f$. above), Bewad asserted the following: That the action of zinc ethyl on nitroethane gave triethylamine oxide, $\left(\mathrm{C}_{2} \mathrm{H}_{5}\right)_{3} \mathrm{~N}=\mathrm{O}$; that the reaction succeeds with only one mole. cule of zinc ethyl; that if two are taken, no amine oxide at all is obtained; that upon reduction the amine oxide forms triethylamine. On the other hand, I showed in my first paper that if two molecules of zinc ethyl are taken the yield of " amine oxide,"

$1 \mathrm{Cf}$. Ber. d. chem. Ges., 21, ref. 479 (I887); 22, ref. 250 (IS88).

2 f. prakt. Chem., 63, 94 (1901).

3 Am. Chem, J, 21, 433 (1899); Ber, d. chem. Ges, 33, I022 (1900). 
instead of vanishing, is more than doubled (a discovery which Bewad seems to have made for himself subsequently). But what is most important is that no amine oxide whatever is formed, but instead ethyl-sec. butylhydroxylamine,<smiles>CCC(C)N(O)CC</smiles>

Bewad was fortunate enough to discover this for himself. The previously noted reduction to triethylamine was erroneous.

My own work on the nitro group took its start from the then unquestioned existence and method of formation of triethylamine oxide. All of the conclusions contained in my first publication are therefore futile, and are herewith withdrawn.' To be sure, the real triethylamine oxide has subsequently been found by Dunstan and Goulding, "and by myself, ${ }^{3}$ but its method of formation does not bring it into connection with the nitro group.

It is to Bewad's explanation of the mechanism of his results, however, that I wish to call attention. To begin with the facts first, Bewad has found that when alphyl nitrites are treated with zinc ethyl and then with water, the products are alcohols and diethyl hydroxylamine (and of course zinc hydroxide); $c . g$.

$$
\begin{aligned}
& {\left[\mathrm{C}_{3} \mathrm{H}_{7} \mathrm{O} . \mathrm{NO}+\mathrm{Zn}\left(\mathrm{C}_{2} \mathrm{H}_{5}\right)_{2}\right]+2 \mathrm{H}_{2} \mathrm{O}=} \\
& \mathrm{C}_{3} \mathrm{H}_{7} \mathrm{OH}+\left(\mathrm{C}_{2} \mathrm{H}_{5}\right)_{2} \mathrm{NOH}+\mathrm{Zn}(\mathrm{OH})_{2} .
\end{aligned}
$$

On the other hand, I have found that when diphenylnitrosamine is treated with zinc ethyl, the products are diphenylamine and diethylhydroxylamine :

$$
\begin{aligned}
{\left[\left(\mathrm{C}_{6} \mathrm{H}_{5}\right)_{2} \mathrm{~N} . \mathrm{NO}+\right.} & \left.\mathrm{Zn}\left(\mathrm{C}_{2} \mathrm{H}_{5}\right)_{2}\right]+2 \mathrm{H}_{2} \mathrm{O}= \\
& \left(\mathrm{C}_{6} \mathrm{H}_{5}\right)_{2} \mathrm{NH}+\left(\mathrm{C}_{2} \mathrm{H}_{5}\right)_{2} \mathrm{NOH}+\mathrm{Zn}(\mathrm{OH})_{2} .
\end{aligned}
$$

If we designate, in these two equations, the group attached to $-\mathrm{NO}$ by $\mathrm{X}$, the two reactions are exactly parallel:

$$
\begin{aligned}
& {\left[\mathrm{X}-\mathrm{NO}+\mathrm{Zn}\left(\mathrm{C}_{2} \mathrm{H}_{5}\right)_{2}\right]+2 \mathrm{H}_{2} \mathrm{O}=} \\
& \mathrm{X}-\mathrm{H}+\left(\mathrm{C}_{2} \mathrm{H}_{3}\right)_{2} \mathrm{NOH}+\mathrm{Zn}(\mathrm{OH})_{2} .
\end{aligned}
$$

It is a reasonable assumption that the mechanism of this reaction is identical in both cases.

In (II), I was able to show, by separating and analyzing the first product, that one molecule each of nitrosamine and zinc ethyl

I Am. Chem. J., 21, 440 (1899).

$2 J$. Chem. Soc., 75, 792 (1899).

s Ber, d. chem. Ges., 33, 1025 (1900). 
unite to form a stable compound, which is subsequently decomposed by water :

$$
\begin{aligned}
& \left(\mathrm{C}_{6} \mathrm{H}_{5}\right)_{2} \mathrm{~N}-\stackrel{\mathrm{N}}{\mathrm{N} \mathrm{H}_{5}} \begin{array}{l}
\mathrm{Zn} \\
\mathrm{O} \\
\mathrm{O} \\
\mathrm{C}_{2} \mathrm{H}_{5}
\end{array}+2 \mathrm{H}_{2} \mathrm{O}= \\
& \left(\mathrm{C}_{6} \mathrm{H}_{5}\right)_{2} \mathrm{NH}+\mathrm{N}_{\mathrm{C}_{2} \mathrm{H}_{5}}^{\stackrel{\mathrm{C}}{-}} \stackrel{\mathrm{CH}_{2} \mathrm{H}_{5}}{-}+\mathrm{Zn}(\mathrm{OH})_{2} .
\end{aligned}
$$

The decomposition products agreed closely with the calculated yield (diphenylamine quantitative, hydroxylamine over 50 per cent.). Bewad, on the other hand, led by the analogy of the carbonyl group, $-\mathrm{CO}$, assumed that two molecules of zinc ethyl would be required, did not try to use merely one, did not separate or analyze his addition product, and gives the following equation :

$$
\begin{aligned}
& \mathrm{R}-\mathrm{O}-\mathrm{NO}+2 \mathrm{Zn}\left(\mathrm{C}_{2} \mathrm{H}_{5}\right)_{2}=
\end{aligned}
$$

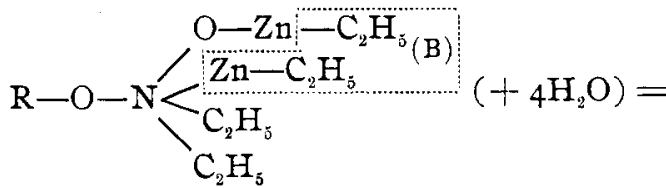

$$
\begin{aligned}
& \mathrm{R}-\mathrm{OH}+\left(\mathrm{C}_{2} \mathrm{H}_{5}\right)_{2} \mathrm{NOH}+\mathrm{Zn}(\mathrm{OH})_{2}+\left[\mathrm{Zn}(\mathrm{OH})_{2}+{ }_{2} \mathrm{C}_{2} \mathrm{H}_{6}\right]
\end{aligned}
$$

I have labeled the two zinc ethyl molecules in order to point out that molecule (B) simply adds on to the first product, and then splits off again, for no other apparent purpose than to gratify Bewad's sense of analogy.

From the above it would appear that we have a very general reaction of the nitroso group when not attached directly to carbon. In this latter case, I have found nitrosobenzene to behave altogether differently, for reasons that cannot yet be understood. ${ }^{1}$

One seeks in vain for any analogy between this general reaction of nitroso compounds and the behavior of carbonyl groups with zinc ethyl. Bewad compares the former to the reaction of alde-

${ }^{1}$ Cf. Am. Chem. J., 21, 442 (1899). 
hydes, formic and oxalic esters, etc.' But in all of these instances one molecule of zinc alphyl is able to introduce only one hydrocarbon radical.

Aldehyde :

$$
\mathrm{CH}_{3} \mathrm{C}_{\mathrm{H}}^{\mathrm{O}}+\mathrm{Zn}\left(\mathrm{C}_{2} \mathrm{H}_{5}\right)_{2}=\mathrm{CH}_{3}-\frac{\mathrm{C}-\mathrm{C}_{2} \mathrm{H}_{3}}{\mathrm{H}_{3}} .
$$

Ethyl formate:

Methyl oxalate :

$$
\mathrm{H}_{\mathrm{OC}_{2} \mathrm{H}_{3}}^{\mathrm{C}=\mathrm{O}}+\mathrm{Zn}\left(\mathrm{CH}_{3}\right)_{2}=\mathrm{H}-\stackrel{\mathrm{C}-\underset{\mathrm{CH}_{3} \mathrm{H}_{5}}{\mathrm{OZnCH}_{3}}}{\mathrm{OCO}_{2}} .
$$

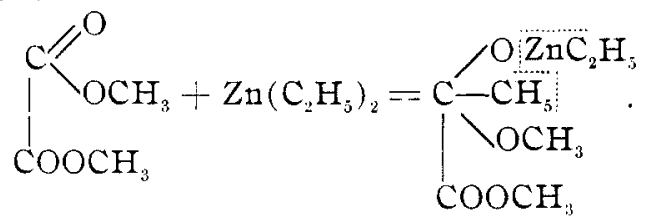

The behavior of the nitroso group is therefore unique, and in no way parallel to that of carbonyl.

The behavior of nitro compounds with zinc ethyl is much more complicated. As Bewad's equations are highly complex, as he is guided wholly by the misleading carbonyl analogy, and as some of his formulas are self-contradictory, it is not necessary to devote further time to this side of his work. The facts are more important for the present. Bewad finds that zinc ethyl and nitroethane react slowly. If the mixture is decomposed after a few days, the main products are unchanged nitroethane and secondary nitrobutane. . If allowed to stand several months, the nitro-paraffins diminish in amount, and the main product is then ethyl sec. butyl hydroxylamine :<smiles>CCCCC(C)N(O)CC</smiles>

An entirely similar reaction was obtained with numerous other nitroparaffins and zinc alphyls, provided that primary or secondary nitroparaffins are taken. (Zinc methyl with nitromethane forms an exception.)

1 tor cit., p. I to. 
It is not worth while to supplement Bewad's speculations by others equally unfounded; but the following facts seem to stand out plainly. First, that the primary action of zinc alphyl is to alkylate, and that this alkylation is independent of the subsequent alteration of the nitro group; proof : nitrobutane is formed before the hydroxylamine. Second, that the new nitroparaffine thus formed is not present in the free state, but probably in the shape of a zinc alphyl salt; proof : if a primary nitro compound is the original substance, the resulting hydroxylamine contains a secondary radical; whereas if we start from a secondary nitroparaffin, we get a tertiary radical in the hydroxylamine. If free secondary nitroparaffins are first formed, we should obtain tertiary radicals in both instances. Third, that this intermediate product is capable of adding on zinc alphyl in such a way that one hydrocarbon radical attaches itself to nitrogen. This addition depends upon the previous compound, and is not wholly due to the nitro group.

The last conclusion needs further details. Bewad, in an experiment to which he himself attached but little importance, found that a tertiary nitroparaffine was simply reduced to the corresponding hydroxylamine without alkylation,

$$
\left(\mathrm{CH}_{3}\right)_{3} \mathrm{C}-\mathrm{NO}_{2} \rightarrow\left(\mathrm{CH}_{3}\right)_{3} \mathrm{C}--\mathrm{N}<_{\mathrm{OH}}^{\mathrm{H}}
$$

the absence of a mobile hydrogen atom, with its consequent replacement by zinc alphyl, seems to prevent alkylation of the nitrogen atom.

On the other hand, we may have here a specific reaction of the nitro and the nitroso group when directly attached to carbon. The main product when nițrosobenzene acts upon zinc ethyl is phenylhydroxylamine. ${ }^{1}$ Nitrobenzene also gives a small amount of phenylhydroxylamine." Bewad found only aniline in this last case, but that is an error in fact ; besides phenylhydroxylamine, I was able to isolate small amounts of aniline and ethyl aniline. Here again it will be best to refrain from speculative equations until further facts are obtained.

It is clear, however, that in the action of zinc ethyl on nitrogen oxygen compounds we have a process that is by no means analogous to the behavior of carbonyl compounds; that different

${ }^{1}$ I,achman: $A m$. Chem, $J$, 21, 343 (1899).

2 Ibid. 
classes of these nitrogen oxygen compounds behave altogether differently ; and that only for the very limited group of nitroso compounds whose nitrogen atom is not directly linked to carbon is there anything like a clear comprehension of the details of the reaction.

ETGENE, OREGON, August, IgOI.

\section{REVIEW.}

\section{A REVIEW OF SOME RECENT PROGRESS IN ORGANIC CHEMISTRY. ${ }^{1}$}

It is with deep regret that I am obliged, at this first attempt of the Section, to bring a systematic review of recent progress in chemistry, to ask your kind indulgence for the many omissions and defects in this summary of the recent history of organic chemistry. The time at my disposal has been very short; the subject-matter, I need not say, is all too extensive. A painstaking German statistician has calculated that over I0,000 pages are needed to record the annual progress of organic chemistry, I have endeavored to report upon the work of some three years; the printed pages, if laid side by side, would make a solid field of type covering some 6,000 square feet-a large area for a critic to weed over by lamplight. Under the circumstances, I have ventured to select a few of what have seemed to me the more important achievements, and have called this paper "A Review of Some Recent Progress."

\section{NOMENCLATURE AND REGISTRATION.}

The important problem of naming organic compounds has not advanced much beyond the work of the Geneva conference in I 893. It will be remembered that the Geneva rules are fairly. satisfactory only for the simpler fatty compounds; they are too cumbersome for complex fatty derivatives, and fail almost completely with the vast majority of ring compounds. It is still possible for ten chemists to describe one and the same substance under ten different names, without recognizing the identity of their descriptions. An important discovery by M. M. Richter, however, promises to be of great assistance in simplifying this difficulty. Richter has pointed out that while the name of an organic compound may not be characteristic, its cmpirical composition is absolutely definite. He has, therefore, undertaken the truly Herculean task of gathering nearly 80,000 organic substances together into a dictionary, grouping these according to the increasing complexity of their atomic composition. The result is a

\footnotetext{
1 Read at the Denver meeting of the Society, Angust, Igor.
} 